DOI https://doi.org/10.32841/2409-1154.2021.49-1.13

\author{
Yemelyanova O. V., \\ Candidate of Philological Sciences, Associate Professor, \\ Associate Professor at the Department of Germanic Philology \\ Sumy State University \\ Kucheriavenko V.A., \\ Master's Student at the Department of Germanic Philology \\ Sumy State University
}

\title{
STRUCTURAL AND LINGUISTIC FEATURES OF THE ARTIST INTERVIEW
}

Summary It is determined that the interview is one of the most dynamically developing journalistic genres and is dialogical in form. The main features of the interview are described and defined; they are: participants' awareness of simultaneous or further distribution of the talk either in the media or online, the public nature of the talk, the interviewee is a high-profile figure, face-to-face interaction between the journalist and the interviewee, the question-and-answer format, dual addressability, which is a very peculiar characteristic of the interview as the speakers - the journalist (the interviewer) and his communicative partner(s) (the interviewee(s)) take part in the talk to generate some important and interesting information, but at the same time, there is another participant of the communication - the audience (a reader, listener, TV-viewer).

The interview is aimed at offering the audience some important information supplied by a renowned and reliable source - the interviewee, comprehensive disclosure of a specific fact with reference to the interviewee, as well as a statement of public opinion about a particular event.

It is pointed out that the artist interview, presented online, is characterised by the following structural elements: a headline that being memorable and informative encompasses the name, surname, the job or position of the interviewee + preposition $o n+$ the main topic discussed in the interview, or it can include the name, surname and the interviewee's direct quotation; the interviewee's photograph; one sentence long summary; an introductory part; the text of the interview with some artistic works of the interviewee(s). It is determined that during the artist interview, the journalist employs a wide range of questions, namely: general, special, if-questions with the Second Conditional. The construction why + auxiliary verb $d o+$ adverb not + pronoun welyou is often used to make a suggestion. The imperative mood serves the purpose of controlling the direction of the interview. Indirect questions are also actively used.

Key words: an artist interview, a journalistic genre, a dual addressee, an interviewer, an interviewee.

Formulation of the problem. Many modern researches $[1 ; 2 ; 3]$ focus on the interview studies, as it is a multifaceted phenomenon. For linguists $[4 ; 5]$ interviews are of interest being a specific journalistic genre. At the same time, the interview is dialogical in nature offering rich material for communication studies. As O. Borysov points out, "the lexeme interview represents the interview as "a conversation between a journalist or radio or television presenter and a person of public interest, used as the basis of a broadcast or publication" [6].

Modern scholars analyse the concept of the interview, its preparation process, offer interview classification (M. Lukina [7]), focus on generic peculiarities of the interview (G. Apalat [8]), study its contrastive parameterization (O. Borysov [6]), pragmatic aspects (N. Gapotchenko [9], T. Popova [10], O. Protsenko [4]), emotional impact on the addressee (T. Pshenychna [2]). Despite quite a number of philological studies of the interview, a thorough analysis of the artist interview has not been done so far, that constitutes the topicality of the research, conducted within the framework of the anthropocentric paradigm. The aim of the study is to estimate structural and linguistic features of the artist interview.

The subject matter of the study is the artist interview posted online. The specific topic of the research is the comprehensive analysis of structural and linguistic peculiarities of the artist interview.

Presentation of the main research material. Nowadays, interviewing is one of the fastest growing journalistic genres. In recent years, publications dialogic in structure have become exceptionally popular in the media. The tendency of the interview popularity both among the journalists and the addressee-readers/listeners is explained, first of all, by the growing interest in personal opinions and assessments, trust in the interviewee's expertise in a certain area.

An interview as a genre is characterised by a dialogical form of presenting information. The basic features of this genre are: 1) the focus of the conversation on its dissemination in the media; 2) the public nature of the talk; 3 ) the interviewee is a socially prominent figure; 4) personal communication between the journalist and the respondent; 5) question-answer format; 6) dual addressability as the interview is designed not only to inform and influence the journalist, but also the audience [2, p. 9].

It is important to emphasize that communication between two (or more) participants in the course of the interviewing process is not a goal in itself: the information obtained during the interview is intended not only to satisfy the interest of the participants or for personal, professional, corporate purposes. In the interview, the interlocutors - the journalist (the interviewer) and his partner(s) (the interviewee(s)) - participate in the talk to satiate the strive for the information of the third main participant of communication the addressee-reader/listener/TV viewer (the addressee-audience). According to Z. Smelkova, a journalist (an interviewer), addressing his direct addressee (an interviewee), builds up a special journalistic 
drama of the talk taking into account the specifics of the information perception by the future reader (mass addressee) [11, p. 168]. This determines one of the main features of the interview - dual addressability, each of the interview participants addresses not only their direct communication partner(s), but also another addressee the mass addressee, who are readers of the newspaper, magazine, online journal as well as radio listeners and TV viewers.

This feature is noted by most researchers of the interview, because the presence of the other addressee significantly affects the linguistic composition of the participants' remarks, they take into account the potential audience if they want to succeed in communicating their ideas [5, p. 7]. The dual addressee is primarily reflected in the speech of the interviewer. The explication of the dual addressee at the linguistic level is foregrounded by: 1) etiquette formulas of double greeting; 2) obligatory introduction of the interviewee to the TV viewers; 3 ) metatext markers of the beginning, end, changes of the topic meant both for the interviewee and the audience; 4) commenting on the intentional aspect of the issue [10, p. 24].

The purpose of the interview is to convey important information from reliable sources, comprehensive disclosure of a specific fact with reference to the interviewee, as well as a statement of public opinion about an event. At the same time, such goals as informational, cognitive, and educational are invariably pursued. This genre allows to disclose the inner world of a person being interviewed, to project his thoughts, dreams, to convey the mood. The genre of an interview is an efficient form not only to inform but to persuade as well.

Macmillan online dictionary offers the following definitions of the word artist: (1) someone who makes paintings, sculptures etc; (2) a professional performer in music, dance, or the theatre; (3) someone who writes, makes films, or writes music with great skill; (4) someone who shows a lot of skill in their work [12]. Choosing the artist interview as the subject area of the study, it should be mentioned that we understand this term broadly as the interview with the person who is highly skilled in what they do.

The research material shows that the artist interviews presented online are characterised by certain structural peculiarities. The structural elements of the artist interview are the following:

(1) the headline that must be both catchy and informative. The analysis of the headlines reveals a certain formula that the journalist, who usually performs the role of the interviewer as well, follows. It comprises the name, surname, the job or position of the interviewee + preposition on + the issue being covered in the interview. For example:

"Austin's Star Art Dealer Lisa Russell on How She Went From Selling Rembrandt to Banksy" [13].

"New York Cultural Leaders Gonzalo Casals and Kemi Ilesanmi Compare Notes on the Threats - and Opportunities - of the Pandemic Era" [14].

Another way to give the interview a heading is to use the name, surname and the direct quote. For example: "Eva and Franco Mattes: 'Technology does not create the social problems we so often criticise", [15].

To grab an addressee-reader's attention right on the spot the journalist can put a provocative question in the headline and offer an intriguing answer to it. For example:

"How Far Would You Go for Your Art? Julian Charrière Went to the North Pole (and Got in Trouble With the Law)" [16];
(2) the photograph of the person/persons being interviewed. For example [17]:

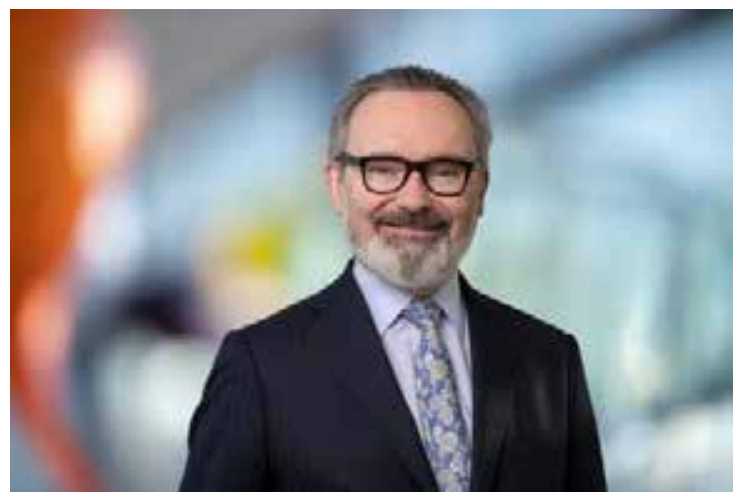

(3) a very concise summary that is only one sentence long. For example:

"Jean Gazançon, CEO of ARTE Generali, on the Vanguard of Art Insurance and Technology (Yes, It Involves an App) [17] the headline.

Gazançon explains why cutting-edge technologies are essential to the continued stewardship of cultural history" [17] the summary;

(4) an introductory part that could vary drastically in length and be either only 9 lines long or much longer - up to 34 lines. For example:

"Art insurance doesn't have a particularly glamorous reputation, but the seemingly fusty process of choosing the right coverage is one of the most consequential decisions a collector can make. Hoping to clear away the mental cobwebs and arcane paperwork of the art-insurance process is ARTE Generali, the new unit of Italian insurance titan the Generali Group. ARTE Generali is applying cutting-edge technological knowhow to the process of ensuring a collection (there's even an easy-to-use app).

We recently spoke with Jean Gazançon, the company's CEO, about how ARTE Generali is shaking up the art-insurance game and what he sees as technology's role in forming a better art world" [17].

The research material demonstrates that in the introductory part the journalist resorts to the inclusive pronoun we that is meant to create in the addressee-reader's mind the feeling of belonging to the exceptional group, that is lucky enough to communicate with the popular, talented people;

(5) the text of the interview that can be punctuated by the interviewee(s)'s creative works. For example:

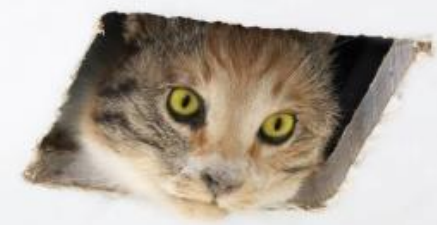


Eva \& Franco Mattes's Ceiling Cat (2016) Collection of the San Francisco Museum of Modern Art (SFMOMA). Photo: Katherine Du Tiel [15].

The analysed data show that the range of the questions asked during the artist interview differs greatly. They can be:

- straightforward special questions. For example: "What have the last few months been like for you and your organizations?" [14].

The journalist can ask two interrelated special question one after another. For example: "What is the most challenging part of running a gallery and what have been the biggest changes in the gallery market since you started?" [13];

- questions with the Second Conditional and if-questions are favourites among the interviewers. For example: "If you were not an art dealer, what would you be doing?" [13].

"How would you describe that shared aesthetic?" [18];

$=$ the use of the question word why + auxiliary verb $d o+$ adverb not + pronoun we/you comes as a viable option to make a suggestion being certain that the interviewee is sure to support it. For example: "Why don't we start where your own career did - with Duchamp. Tell me, how did you first meet Marcel Duchamp?" [19].

The use of the imperative mood + special question in the second consecutive part of the query (Tell me, how did you first meet Marcel Duchamp?) is quite efficient as it explicitly invites the interviewee to give some detailed information;

- general questions that are also in the interviewer's arsenal. For example: "Do you each have a favorite camera?" "Are there some photographers you're both interested in?" [18].

This type of questions works especially well when the journalist is interviewing a couple;

- the indirect questions. As the indirect questions sound more polite, the interviewer often resorts to them at the very beginning of the interview not to sound too pushy and encourage the interviewee to give a comprehensive answer. For example: "Can you tell me a little bit about your backgrounds and how you each wound up working in the photography world?" [18].

The research material shows that in the course of the artist interview the journalist can make some comments that are meat to:

- ensure that the interview runs smoothly and in the right direction. For example: "You've mentioned that the inspiration for this show came when you were preparing for the Antarctic Biennale in 2017. I want to start there. Can you tell me what your relationship to the region is?" [16];

- pay the interviewee a delicate compliment that can be either explicit, for example: "It's also a very beautifully shot film" [16],

or implicit, for example: "Here I should point out that your wife, Dodie Kazanjian, is a very accomplished journalist and curator in her own right, and she's your secret weapon, reportorially speaking" [19];

- express the emotions to encourage the interviewee to give some more interesting details. For example: "Yikes."

"An unbelievable coup" [19].

Conclusions and prospects for further research. The interview, and the artist interview in particular, is an independent journalistic genre, characterised by a dialogical form of material presentation. The most important feature of this genre is its dual addressability, as the interviewer addresses not only the direct communication partner - the interviewee(s), but also an invisibly present other addressee (a reader, listener, TV-viewer).
The conducted research shows that the artist interview presented online has specific structural elements, namely: a heading that is memorable and informative and can include the name, surname, the job or position of the interviewee + preposition on + the key issue discussed in the interview, or it can comprise the name, surname and the direct quote of the interviewed person; the interviewee(s)' photograph; one sentence long summary; an introductory part; the text of the interview with some photos of artistic works of the interviewee(s). In the course of the artist interview, the spectrum of the questions asked may vary considerably. These are general, special questions, if-questions with the Second Conditional. The interviewer often resorts to why + auxiliary verb $d o+$ adverb not + pronoun we/you type of the question to make a suggestion. The use of the imperative mood is also actively employed to turn the course of the interview in the preferable direction. Indirect questions, being more polite, are also favoured by the journalists.

The prospects of the further research we see in the comprehensive analysis of the English artistic interview focusing on the non-linguistic means employed.

\section{References:}

1. Dürscheid C. Medien, Kommunikationsformen, kommunikative Gattungen. Linguistik online. 2005. URL: https:/bop.unibe.ch/ linguistik-online/article/view/752 (дата звернення: 5.06.2021).

2. Пшенична Т.О. Мовленнєвий вплив на емоції адресата інтерв'ю : автореф. дис. ... канд. наук із соц. ком. : 27.00.06. Київ, 2011. 17 с.

3. Мозолевська А. С. Лінгвопрагматичний аспект інформативності інтерв'ю (на матеріалі сучасної французької преси) : дис. ... канд. філол. наук : 10.02.05. / Київ. нац. ун-т ім. Т. Шевченка Київ, 2014. $206 \mathrm{c}$.

4. Проценко О. В. Прагматична самокорекція комунікантів в українському спонтанному мовленні (на матеріалі теле- та радіотекстів): дис. ... канд. філол. наук: 10.02.01. / Київ. нац. ун-т ім. Т. Шевченка. Київ, 2006. 205 с.

5. Прокопенко А. В. Інтерв'ю в передвиборчому американському дискурсі: структурно-семантичний та комунікативно-прагматичний аспекти : автореф. дис. ... канд. філол. наук : 10.02.04. Донецьк, 2013. 20 с.

6. Borysov, O. O. (2018). Contrastive Parameterisation of the Interview as a Genre of British and Ukrainian Media Spaces. Scientific Journal of National Pedagogical Dragomanov University. 2018, Series 9. Current Trends in Language Development, 18. 33-45. DOI: https:// doi.org/10.31392/NPU-nc.series9.2018.18.03

7. Лукина М.М. Технология интервью. Москва : Аспект Пресс, 2003. 191 c.

8. Апалат Г. П. Структура, семантика і прагматика текстів-інтерв’ю (на матеріалі сучасної англомовної преси) : автореф. дис. на здобуття наук, ступеня канд. філол. наук: спец. 10.02.04 «Германські мови». Київ, 2003. 19 с.

9. Гапотченко Н. Є. Комунікативно-прагматична організація діалогічних комунікативних блоків текстів інтерв'ю (на матеріалі сучасної преси). Наука і сучасність: 36. наук. пр. Київ : Логос, 2004. С. 238-244.

10. Попова Т.И. Телевизионное интервью: семантический и прагматический аспекты : автореф. дис. ... д-ра филол. наук : 10.01.10. Санкт-Петербург, 2004. 40 с.

11. Смелкова 3.С. Риторические основы журналистики: Работа над жанрами газеты. Москва : Флинта: Наука, 2002. 318 с.

12. Macmillan Dictionary. URL: https://www.macmillandictionary.com/ dictionary/british/artist (дата звернення: 5.06.2021).

13. Austin's Star Art Dealer Lisa Russell on How She Went From Selling Rembrandt to Banksy. URL: https://news.artnet.com/partner-content/ lisa-russell-west-chelsea-contemporary (дата звернення: 5.06.2021). 
14. Kinsella E. New York Cultural Leaders Gonzalo Casals and Kemi Ilesanmi Compare Notes on the Threats-and Opportunities-of the Pandemic Era. URL: https://news.artnet.com/multimedia/gonzalocasals-kemi-ilesanmi-1916951 (дата звернення: 5.06.2021).

15. Carrigan M. Eva and Franco Mattes: 'Technology does not create the social problems we so often criticise'. URL: https://www. theartnewspaper.com/interview/eva-franco-mattes (дата звернення: 5.06.2021).

16. Dafoe T. How Far Would You Go for Your Art? Julian Charrière Went to the North Pole (and Got in Trouble With the Law). URL: https://news.artnet.com/art-world/julian-charriere-on-his-heady-ecoconceptualism-1796415 (дата звернення: 5.06.2021)

17. Jean Gazançon, CEO of ARTE Generali, on the Vanguard of Art Insurance and Technology (Yes, It Involves an App). URL: https:// news.artnet.com/partner-content/jean-gazancon-arte-generaliinterview (дата звернення: 5.06.2021).

18. White K.'We Each Bring to the Table What the Other Is Lacking': Photographers Alana Celii and Daniel Dorsa on Their Classic New York Love Story. URL: https://news.artnet.com/art-world/alana-celiidaniel-dorsa-portraits-of-love-1782210 (дата звернення: 5.06.2021).

19. Goldstein A. The Artist Whisperer: Legendary Journalist Calvin Tomkins on What Duchamp Taught Him, and How He Managed to Track Down David Hammons. URL: https://news.artnet.com/the-biginterview/calvin-tomkins-lives-artists-interview-part-1-1734057 (дата звернення: 5.06.2021).

Смельянова О. В., Кучерявенко В. А. Структурні та лінгвістичні особливості інтерв'ю 3 творчою особоюпрофесіоналом

Анотація. 3'ясовано, що інтерв'ю є одним із журналістських жанрів, що активно розвивається, має діалогічну форму, що зумовлює його популярність у засобах масової інформації. Описано та визначено ключові особливості жанру інтерв'ю, до них належать: орієнтованість бесіди на її одночасне або подальше розповсюдження в засобах масової інформації або в Інтернеті, публічний характер розмови зі знаною багатьма особою, особистісна взаємодія між журналістом та респондентом, формат «запитання-відповідь», подвійна адресованість, що є специфічною характеристикою інтерв'ю, оскільки співрозмовники журналіст (інтерв'юер) та його комунікативний партнер(и) (респондент(и)) - беруть участь у розмові, щоб генерувати якусь важливу і цікаву інформацію, але водночас $є$ інший учасник спілкування - аудиторія (читач, слухач, глядач).

Інтерв'ю спрямоване на те, щоб запропонувати аудиторії деяку важливу інформацію, надану відомим і надійним джерелом - респондентом, всебічне розкриття конкретного факту з посиланням на респондента, а також виклад громадської думки про конкретну подію.

Слід зазначити, що інтерв'ю з творчою особою-професіоналом, представлене в Інтернеті, характеризується такими структурними елементами, як заголовок, який упадає в око та є інформативним, включає ім'я, прізвище, посаду респондента + прийменник on + основну тему, обговорювану під час інтерв'ю, або він може включати ім'я, прізвище і пряме цитування респондента; фотографію респондента; коротку анотацію, представлену одним реченням; вступну частину; текст інтерв'ю 3 деякими художніми роботами респондента(ів). Визначено, що під час інтерв'ю $з$ творчою особою-професіоналом журналіст використовує широкий спектр питань, а саме: загальні, спеціальні, if-питання з Conditional II. Конструкція why + допоміжний дієслово do + прислівник $n o t+$ займенник we/ уои активно уживана для пропонування певної дії. Наказовий спосіб сприяє контролю напрямку перебігу інтерв'ю. Також активно використовуються непрямі питання.

Ключові слова: інтерв'ю 3 творчою особою-професіоналом, журналістський жанр, подвійний адресат, інтерв'юер, респондент. 